\title{
Erratum zu: Empirischer Teil
}

\section{Erratum zu: \\ Kapitel 4 in: A. F. Nebe, Humor und erfolgreiche Kinderfilme, https://doi.org/10.1007/978-3-658-23329-7_4}

Die originale Version dieses Buches wurde mit verschobenen Elementen in der Abb. 43 publiziert. Diese Abbildung ist nun korrigiert und wird wie nachstehend dargestellt.

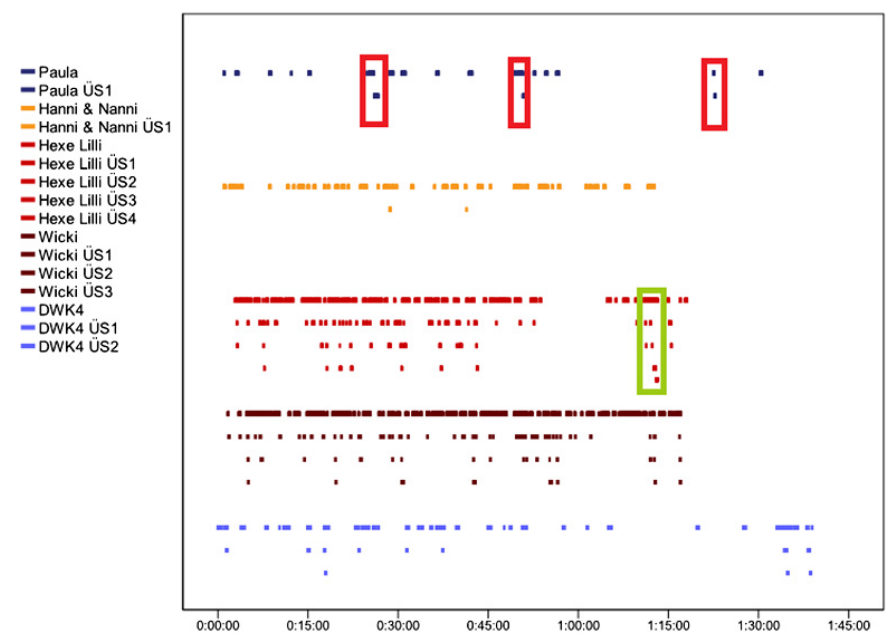

Abbildung 43: Grafischer Vergleich aller Filme in Bezug auf die Humorstruktur (synchronoptische Darstellung).

Quelle: eigene Erhebung.

Die korrigierte Version des Kapitels ist verfügbar unter https://doi.org/10.1007/978-3-658-23329-7_4

(C) Springer Fachmedien Wiesbaden GmbH, ein Teil von Springer Nature 2019 